\title{
Transposition
}

Musique et Sciences Sociales

Hors-série 2 | 2020

Sound, Music and Violence

\section{Culprit or Accomplice: Observations on the Role and Perception of Music in Violent Contexts in the Sierra Leone War}

Coupable ou complice : observations sur le rôle et la perception de la musique dans des contextes violents durant la guerre en Sierra Leone

\section{Cornelia Nuxoll}

\section{OpenEdition}

Journals

\section{Electronic version}

URL: http://journals.openedition.org/transposition/4382

DOI: $10.4000 /$ transposition.4382

ISSN: 2110-6134

Publisher

CRAL - Centre de recherche sur les arts et le langage

\section{Electronic reference}

Cornelia Nuxoll, «Culprit or Accomplice: Observations on the Role and Perception of Music in Violent Contexts in the Sierra Leone War », Transposition [Online], Hors-série 2 | 2020, Online since 15 March 2020, connection on 16 April 2020. URL : http://journals.openedition.org/transposition/4382 ; DOI : https://doi.org/10.4000/transposition.4382

This text was automatically generated on 16 April 2020.

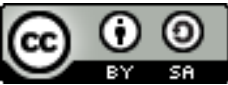

La revue Transposition est mise à disposition selon les termes de la Licence Creative Commons Attribution - Partage dans les Mêmes Conditions 4.0 International. 


\title{
Culprit or Accomplice: Observations on the Role and Perception of Music in Violent Contexts in the Sierra Leone War
}

\author{
Coupable ou complice : observations sur le rôle et la perception de la musique \\ dans des contextes violents durant la guerre en Sierra Leone
}

Cornelia Nuxoll

1 In the 1990s, combatants of the Sierra Leonean Revolutionary United Front (RUF) often used music in the context of war to justify, prepare for, and accompany violent attacks. Diving deeper into this matter leads to further questions: Which were the songs that became part of the "rebel soundtrack" and what was their appeal to the RUF? Was music an accessory to or the driving force behind their violent actions? And how do the musicians who released the songs, as well as the civilians who fell victim to violent strategies involving these songs, view the rebels' appropriation of music for war?

\section{Innocuous or Dangerous: Agency of Music}

2 When I began to study the role and impact of music in conflict situations and the way music may be used to incite, accompany and legitimise violence, my research focus was time and again met with some resistance. The idea that music could be used for ulterior motives stands in stark contrast to the widely held notion that music is intrinsically good, an all-time positive force and a unifying, universal language. On the other hand, it has been suggested that listening to certain types of music with "violent lyrics" ultimately causes aggressive behaviour in the listener. Based on my field research in post-war Sierra Leone, music used in war does not necessarily have to be perceived as either good or bad. Rather, former combatants, civilians and musicians positioned 
music in a neutral way, looking beyond its appropriation in the context of violence in order to preserve their relationship with it.

3 As Tia DeNora and others have pointed out, people turn to music as a framing device and mood regulator. It is often used as an enhancer (or diffuser), playing into and amplifying (or dispelling) the listener's emotional disposition. Music provides resources to connect and reconnect with oneself and one's emotions. However, it is not music alone or any intrinsic property it contains that acts as a causal stimulus that creates or changes emotions in a person. Instead, music's effect is attributable: its power cannot be abstracted from the context in which it is used and experienced. Music is a resource that people utilise to gain access to emotional experiences and responses as they look for and deal with dormant issues not yet fully grasped or negotiated. ${ }^{1}$ Music is considered an agentive force because engaging with it facilitates a state of "entrainment" in which the listener ascribes perceived meanings and purpose to the musical material. ${ }^{2}$ The structuring properties of music allow it to form a significant constitutive means of human action and provide a resource through which personal and social lives can be configured. Music can be used to foster critical consciousness. It may also serve as a referent for action and an ordering device that organises its listeners and performers in real time. ${ }^{3}$

Over the past fifteen years or so, musicological research increasingly addressed the question of music's effective use in post-conflict settings as a tool for peace and reconciliation as well as in processes of nation-building and commemoration. At the same time, there is an increasing amount of studies recognising the use of music as a means of mobilisation and propaganda, and inciting or accompanying violence. Both research approaches assume that music can be instrumentalised to activate as well as intensify the feelings, intentions, and actions of those who hear it or make it. In other words, music is a tool that can be used for belligerent and peaceful means alike. ${ }^{4}$

The following discusses some observations on the role of music made through my fieldwork among the Revolutionary United Front (RUF) of the Sierra Leonean civil war that took place from 1991 to 2002.

\section{Reminiscing about Music after the War. Fieldwork Observations}

6 After decades of increasing state decline due to bad governance, political corruption and economic failure, the newly-formed rebel group RUF attempted to topple the then ruling government. Mostly comprised of disenfranchised young men striving to improve their own and the country's socio-economic conditions, the RUF movement gained some initial sympathy and support from civilians. For various reasons, however, the RUF very soon no longer pursued its political agenda and resorted to indiscriminate violence, brutal robberies, and forced recruitment to sustain itself, which resulted in the complete loss of civilian support. Numerous power changes and various collusive alliances later, the Sierra Leone conflict - by now widely labelled a "senseless war" 5 infamous for its atrocities, blood diamonds and widespread use of underage combatants - was officially declared over in 2002.6

7 Producing only losers, civilians bore the brunt of this conflict, with tens of thousands dead, many more displaced, no significant change in politics and a destroyed 
infrastructure. Until today, many of the root causes of the war remain disturbingly unresolved and most former RUF members never returned home to their families. Instead, they chose to live in anonymity in the bigger cities to avoid any stigmatisation for their active involvement in the war. Although rank and file combatants were granted amnesty after the war, many feared indictments, self-incrimination, retribution and other negative exposure because of their affiliation with the rebel group. When I began my field research in Sierra Leone, there was a concern that former RUF members would be unwilling to engage in dialogue for fear of reprisals.

Early on, however, I realised that the music focus of my research served as a sort of door opener. The emphasis on the role of music and not on the atrocities during the war seemed to present my research in an innocent, benign, perhaps even trivially insignificant context to my interlocutors. My interactions did not necessarily require detailed descriptions of war crimes and human rights violations to obtain information on the role of music among RUF members.

During my interviews, I further stressed my focus on music to my interlocutors to make them feel more at ease, in the hope that this approach would obtain sincere answers rather than prompting defensive or face-saving behaviour. Equally important, however, I wanted to avoid that my research would cause participants to relive potentially distressing and traumatic experiences as perpetrators or victims.

At the outset, my request to speak about music was met with some initial astonishment. At the same time, it was evident how - given the topic - former RUF members visibly relaxed and even enjoyed speaking about this topic precisely because they felt that our conversation was going to be "just about music." It was also apparent that most former rebel fighters had not given music much thought whenever they had looked back on the war before. Once they shifted their focus towards it, however, music swiftly resonated with them as an integral part of the war experience. In conversations with former RUF members, it was striking to see how reminiscing about relevant songs triggered vivid memories of their time as combatants. Discussing the songs that were popular with the RUF notably energised and enthused my interlocutors, the joint singing of commando songs made them smile, generated feelings of past camaraderie, prompting them to be more engaged in group interviews. Their emotional response to remembering and performing some songs ultimately provided me with a better understanding of music's impact during the war years.

11 During interviews, former RUF fighters mentioned specific music genres and songs they listened to that inspired or educated them. They also spoke of commando songs they performed during military training. Over time, my interlocutors brought up more sensitive topics, widening the scope of the role and function of music during the war. As I will discuss in the following section, they gave music examples linked to strongarm tactics and combat action, songs the rebels appropriated as a weapon, or used as an accompaniment to execute violent attacks.

12 The music-focused research proved beneficial in at least two ways: the seemingly "innocuous" nature of the project allowed me easier access to former RUF combatants and helped improve their willingness to share their war experiences with me. At the same time, music served as an excellent means to trigger memories, not only of songs that were meaningful to them at the time, but also of the situations they were in and the emotions they felt when they played and heard these songs again. 


\section{Music and Violence through the Eyes of Perpetrators, Victims and Musicians}

13 In the following, I would like to explore another aspect of the use of music during the conflict, viewed through the eyes of the perpetrator, victim and musician. To give more context, I will briefly introduce some of the musical genres that were most relevant to RUF forces, and why. ${ }^{7}$ I will then discuss how rebels, civilians and the respective artists alike perceive this music linked to violence.

Roots reggae was by far the most preferred music genre among early RUF members. Songs like Bob Marley's War and The Real Situation, It's Not a Crime by Burning Spear or House of Exile by Lucky Dube were described as educational and highly motivating. When former combatants listened to the socially critical lyrics of the songs, they saw many parallels to injustices in their own country and interpreted them as justification to take up arms. For RUF combatants who joined the movement at the beginning, reggae offered a vital source for fostering identities as revolutionary freedom fighters. Many felt that engaging with countercultural music that was also associated with the struggle against Apartheid, was already a political act. They felt that many of the songs had instructive and educational components that raised their awareness for socioeconomic grievances and oppressive political systems. They discussed and interpreted the lyrics amongst each other and aligned them with the political situation in Sierra Leone, with the result that the use of violence in the name of revolutionary resistance was considered necessary and legitimate.

In the context of combat action and executing attacks, the RUF made use of some of the songs of popular local musicians Ahmed Janka Nabay and Steady Bongo. Steady Bongo is what Sierra Leoneans commonly refer to as a "cultural musician" who composes songs that often convey traditional values and moral lessons. During the war, he released several albums and was an instrumental figure in the transitional demobilisation and reconciliation process throughout the post-war period. Touring the hinterland with peace concerts, Bongo performed songs that promoted peace and unity, and his live shows helped to ease tensions between opposing factions. RUF forces enjoyed listening to Steady Bongo even though many of songs condemned the war in general, and rebel conduct in particular. Eeh en was a popular song on love, lovemaking and the dangers of womanising. However, during the war, the song Eeh En was part of rebel attacks. Due to its "rousing cultural beat", former RUF fighters recounted how some of the boldest combatants played it as a personal soundtrack over headphones on portable cassette players while moving into battle, keeping in time with the song's rhythm, pumping themselves up and getting ready to fight. It is interesting to note how combatants turned to music as an external source of energy to transform them into what the situation required of them.

Similarly, and while advancing on targets, RUF forces would play the fast and rhythmically complex Bubu songs by the late singer Ahmed Janka Nabay. Done to confuse, and tempt them out of their houses in order to surround and capture them more easily, local inhabitants were subjected to the loud sound blasting of Nabay's music during village attacks. On other occasions, the rebels sang new lyrics on top of Nabay's songs playing over portable boomboxes. They changed some of the original Bubu lyrics, stripping them of their intended message to suit their agenda, now claiming that the RUF was winning the war and that villagers should join the rebel 
force. The appropriation of these songs was not only a deceptive manoeuvre to expose civilians to psychological stress and lure them out, but it was also a ploy to utilize the same music against the very people Nabay's songs were intended to lend moral support to and promote perseverance in difficult times.

These three music examples represent only a small sample of songs that were used by RUF forces to legitimise, prepare for and accompany violence. Reggae music served as a means to reinforce their political ideology and vindicate their violent response to failed politics. Steady Bongo's rhythmic song helped combatants to generate a certain state of mind to forge ahead and get ready for close combat, harden them as fighters and contain emotions of fear. Janka Nabay's Bubu music was instrumentalised as a tactical and psychological weapon to deceive and terrorise civilians during raids, robbing them of the very songs that were supposed to help them withstand the brutality of the war.

All parties involved in or affected by these strategies - namely RUF forces, civilians and the artists themselves - acknowledge that music was weaponised in the context of violence. Interestingly though, all agents ascribe neutrality, if not a certain sense of "purity" to the different musics in question. During interviews with former RUF combatants, we would discuss whether reggae music incited violence in any way. Former RUF members responded by saying:

Violent? Violent? No, no, no. Reggae is part of life and of course, like I said earlier, it inspires zeal and that is revealing maybe your right to you [...], how things should go. Things should go this way, and maybe if you relate that kind of situation to the prevailing situation in your country, you see where the truth lies. Something like that (Interview with M., Kailahun, November 13, 2010).

Actually, it [reggae] doesn't call for violence, it has a message, something like advocates [sic], it is not about calling for violence, but it calls your mind to reflect [...] it was not about calling you to engage yourself in violence actually, it was only unfortunate because of the war, so that people who decided to reflect, find their own ways and means of bringing agency to the system, but it is not about engaging you or making you to engage yourself into violence; it is about telling you to know your right [...] it's about advocacy. It is not about 'the music was right there and used to inspire people to go into rampage and all whatsoever'..., no, it is about knowing your right and exactly know what to do (Interview with S.J., Kailahun, November 10, 2010).

19 The comments show that reggae was not a direct call to inflict violence, but an important framing device to revaluate their actions. Reggae's capacity of raising awareness with regards to socio-political injustices facilitated violence as a legitimate means to rectify these inequities. Put more simply: Is roots reggae considered violent music? No. Can it be used to justify violent means? Yes.

In an interview with Steady Bongo, the musician shared his own ideas on why the rebels co-opted his music when they were advancing on the battlefield:

So before we left [referring to a trip he made to a rebel stronghold], we went down to Super Sound [a music production studio in Freetown] and then we bought so many of my cassettes, CDs, you know, yeah, we put them in the Jeep that we were using. Because they [RUF] love my music so much, you know. Most of the time when they want to attack a village or a town, they always enter with a loud music and that is my music, you know. I did a track during the war, titled Eeh En, you know, Eeh En is about love making, you know, but the beat I gave, the music was a typical culture beat and danceable, you know, so it was easy for them to use this music. And this music was so popular, you know, so when they are moving, they move with that. They have the tape on their head [carrying portable cassette players and 
headphones or boomboxes], all over, dancing..., they attack people, you know (Interview with Lansana Sheriff, aka Steady Bongo, Freetown, October 28, 2010).

21 Steady Bongo neither seems upset, nor does he seem to condemn the rebels' use of his music during attacks. Instead, to him, it is the appeal of the music's "typical culture beat" that lends itself to the appropriation by rebels, which above all, tells him how popular he was and how good and relatable his music is. The context in which his music is played, what it is used for and by whom seems less relevant to Bongo than its overall popularity. ${ }^{8}$

One of my research assistants, a former soldier in the Sierra Leone army now living in Makeni, remembered the effect weaponised Bubu music had on a civilian who fell victim to one of the rebels' ploys:

I have [know] an old woman. She can never forget this song because when they [the RUF] wanted to attack Kambia, they were playing this music on top of their head [carrying boomboxes]. They [the rebels] enter the people's churches, just people happy, it was Christmas time. Festive time. So the people, all of them joined [the rebels' party] and they thought it's good, not knowing that after ten, fifteen minutes... [he whispers and makes a gesture of something spreading out] [the rebels were] everywhere (Interview with A., Makeni, December 29, 2011).

Another civilian who experienced a similar attack pointed out that she could no longer listen to the Bubu songs for fear of being retraumatised. Nonetheless, she still has fond memories of the songs and stressed that she considers the late Janka Nabay an exceptional artist.

Music seems to trigger memories and conjure images more readily than most other stimuli. For former RUF combatants, remembering the war through music was a mostly positive affair. Even when used in the context of violence, reminiscing the songs that they sung or listened to typically brought back memories of the pleasure of the music itself and less of how it was used. Moreover, the collective singing of some songs recreated moments of camaraderie and a sense of belonging, prompting feelings of pride for having been revolutionaries fighting the good fight. In essence, reminding them of a time when they were driven and felt strong and fearless.

Until today, former RUF combatants still listen to reggae music and hold its profound messages in reverence. Janka Nabay's and Steady Bongo's songs are still considered classic hits. They may not actively listen to the cultural songs anymore. However, they also do not have any bad associations with any of these particular songs, even though, in hindsight, they are critical of their conduct in war and may regret the misappropriation of music for violent means. For those that suffered under the RUF's “musical manoeuvres," Janka Nabay's songs may be forever linked to the trauma they had to endure. Nonetheless, victims are perfectly capable of separating the music from the attack. Similarly, Sierra Leonean musicians Bongo and Nabay who learned about the appropriation of their songs, chose to take the instrumentalisation of their music as a sign of their popularity and disregarded its use for ulterior motives.

It is interesting to note that when former rebels, civilians, and musicians recall the war and music's role in it, they all are protective of the music. In order to maintain their own relationship and personal connection with music, they intuitively preserve music's neutrality by decontextualising it from its use. They do not hold the songs accountable for the abuse they either executed or suffered. Instead, rebels, civilians and musicians acknowledge music's presence in the context of violence, they recognise it has played its part and its use as a tool and weapon, but they dissociate music from the actual 
assault, and in doing so, the music itself remains unscathed. Both victims and perpetrators realise that even though music functioned as an amplification device, it is not music that is to blame. However, there seems to be more at play, given that independently of each other - all parties concerned push to preserve music as untarnished, no matter the circumstances. More research is needed to fully understand why, perhaps, for Sierra Leoneans and humans more generally, music is too important to discredit it or see it tainted in any way.

\section{BIBLIOGRAPHY}

CuzIcK Suzanne "Music as Torture/Music as Weapon", Transcultural Music Review 10, 2006, https:// www.sibetrans.com/trans/a152/music-as-torture-music-as-weapon.

cuzick Suzanne "'You Are in a Place That Is out of the World...': Music in the Detention Camps of the "Global War on Terror"', Journal of the Society for American Music, vol. 2, no. 1, 2008, pp. 1-26.

DENORA Tia, Music-In-Action: Selected Essays in Sonic Ecology, Aldershot, Ashgate, 2011.

DENORA Tia, Music in Everyday Life, Cambridge, Cambridge University Press, 2000.

DENORA Tia, After Adorno: Rethinking Music Sociology, Cambridge, Cambridge University Press, 2003. DENOV Myriam, Child Soldiers: Sierra Leone's Revolutionary United Front, Cambridge, Cambridge University Press, 2010.

FAST Susan and PEGLEY Kip (eds.), Music, Politics \& Violence, Middletown, Wesleyan University Press, 2012.

FRITH Simon, "Music and Identity”, HALL Stuart and DU GAY Paul (eds.), Questions of Cultural Identity, London, Sage Publications, 1996, pp. 108-127.

FRITH Simon, Performing Rites: Evaluating Popular Music, Oxford, Oxford University Press, 1996.

GBERIE Lansana, A Dirty War in West Africa: The R.U.F. and the Destruction of Sierra Leone, Bloomington, Indiana University Press, 2005.

GRANT Morag J., "Musik im Dienst des Massenmords," Musik und Gewalt, BRÖCKER Marianne (ed.), Münster, Verlagshaus Monsenstein und Vannerdat, 2010, pp. 259-268.

GRANT Morag Josephine, "Bagpipes at the Front: Pipers and Piping during Combat in the Great War”, schrAMm Michael (ed.), Militärmusik und Erster Weltkrieg, Bonn, Militärmusikzentrum der Bundeswehr, 2015, pp. 35-67.

HIRSCH Lily E. "Weaponizing Classical Music: Crime Prevention and Symbolic Power in the Age of Repetition," Journal of Popular Music Studies, vol. 19, no. 4, 2007, pp. 342-358.

HIRSCH Lily E., "Do You Really Want to Hurt Me? Music as Punishment in the United States Legal System", Popular Music and Society, vol. 34, no. 1, 2011, pp. 35-53.

HOFFMAN Danny, The War Machines: Young Men and Violence in Sierra Leone and Liberia, Durham (NC), Duke University Press, 2011. 
IBRAHIM Abdullah (ed.), Between Democracy and Terror: The Sierra Leone Civil War, Dakar, Codesria, 2004.

JOHNSON Bruce and CLOONAN Martin, "Killing Me Softly with His Song: An Initial Investigation into the Use of Popular Music as a Tool of Oppression”, Popular Music, vol. 21, no. 1, 2002, pp. 27-39. JOHNSON Bruce and cLoonAn Martin, Dark Side of the Tune: Popular Music and Violence, Aldershot, Ashgate, 2008.

KEEN David, Conflict and Collusion in Sierra Leone, Oxford, James Currey, 2005.

KING Nathaniel, Conflict as Integration: Youth Aspiration to Personhood in the Teleology of Sierra Leone's 'Senseless War', Uppsala, Nordiska Afrikainstitutet, 2007.

NUXoLl Cornelia, “'We listened to it because of the message.' Juvenile RUF Combatants and the Role of Music in the Sierra Leone Civil War", Music \& Politics, vol. 9, no. 1, 2015. DOI: https:// dx.doi.org/10.3998/mp.9460447.0009.104 NUXOLL Cornelia "Borrowed Tunes. Commando and Morale Booster Songs in the Sierra Leone War", Transposition, no. 4, 2014. DOI: https://dx.doi.org/10.4000/transposition.598 o'CONNELl John Morgan and CASTElo-Branco Salwa El-Shawan, Music and Conflict, Chicago, University of Illinois Press, 2010.

PETERS Krijn, War and Crisis of Youth in Sierra Leone, Cambridge, Cambridge University Press, 2011. RICHARDS Paul, Fighting for the Rainforest: War, Youth and Resources in Sierra Leone, Oxford, International African Institute, 1996.

SLOBODA John, “Music Structure and Emotional Response: Some Empirical Findings", Psychology of Music, vol. 19, no. 2, 1991, pp. 110-120.

SLOBODA John, Exploring the Musical Mind: Cognition, Emotion, Ability, Function, Oxford, Oxford University Press, 2004.

TRUTH AND RECONCILIATION COMMISSION, Witness to Truth: Report of the Sierra Leone Truth \& Reconciliation Commission, vol. 3A, 2004.

URBAIN Olivier (ed.), Music and Conflict Transformation: Harmonies and Dissonances in Geopolitics, London, I.B. Tauris, 2008.

\section{NOTES}

1. See SLOBODA John, Exploring the Musical Mind: Cognition, Emotion, Ability, Function, Oxford, Oxford University Press, 2004; SLOBODA John, "Music Structure and Emotional Response: Some Empirical Findings", Psychology of Music, vol. 19, no. 2, 1991, pp. 110-120; DENORA Tia, Music in Everyday Life, Cambridge, Cambridge University Press, 2000; FRITH Simon, "Music and Identity", HALL Stuart and DU GAY Paul (eds.), Questions of Cultural Identity, London, Sage Publications, 1996, pp. 108-127; FRITH Simon, Performing Rites: Evaluating Popular Music, Oxford, Oxford University Press, 1996.

2. DENORA, Music in Everyday Life, p. $94 \mathrm{ff}$.

3. See DENORA, Ibid.; DENORA Tia, Music-In-Action: Selected Essays in Sonic Ecology, Aldershot, Ashgate, 2011; DENORA Tia, After Adorno: Rethinking Music Sociology, Cambridge, Cambridge University Press, 2003.

4. See for example o'CONNELl John Morgan and CASTELO-BRANCo Salwa El-Shawan, Music and Conflict, Chicago, University of Illinois Press, 2010; URBAIN Olivier (ed.), Music and Conflict Transformation: 
Harmonies and Dissonances in Geopolitics, London, I.B. Tauris, 2008; JOHNSON Bruce and CLOONAN Martin, "Killing Me Softly with His Song: An Initial Investigation into the Use of Popular Music as a Tool of Oppression", Popular Music, vol. 21, no. 1, 2002, pp. 27-39; JOHNSON Bruce and CLOONAN Martin, Dark Side of the Tune: Popular Music and Violence, Aldershot, Ashgate, 2008; CUZICK Suzanne "Music as Torture/Music as Weapon", Transcultural Music Review 10, 2006, https:// www.sibetrans.com/trans/a152/music-as-torture-music-as-weapon; cuzIcK Suzanne "'You Are in a Place That Is out of the World...': Music in the Detention Camps of the 'Global War on Terror"', Journal of the Society for American Music, vol. 2, no. 1, 2008, pp. 1-26; HIRSCH Lily E. "Weaponizing Classical Music: Crime Prevention and Symbolic Power in the Age of Repetition," Journal of Popular Music Studies, vol. 19, no. 4, 2007, pp. 342-358; HIRSCH Lily E., "Do You Really Want to Hurt Me? Music as Punishment in the United States Legal System", Popular Music and Society, vol. 34, no. 1, 2011, pp. 35-53; GRANT Morag J., "Musik im Dienst des Massenmords," Musik und Gewalt, BRÖCKER Marianne (ed.), Münster, Verlagshaus Monsenstein und Vannerdat, 2010, pp. 259-268; GRANT Morag Josephine, "Bagpipes at the Front: Pipers and Piping during Combat in the Great War", scHRAMм Michael (ed.), Militärmusik und Erster Weltkrieg, Bonn, Militärmusikzentrum der Bundeswehr, 2015, pp.35-67; FAST Susan and PEGLEY Kip (eds.), Music, Politics \& Violence, Middletown, Wesleyan University Press, 2012.

5. See for example ibRAHim Abdullah (ed.), Between Democracy and Terror: The Sierra Leone Civil War, Dakar, Codesria, 2004; KING Nathaniel, Conflict as Integration: Youth Aspiration to Personhood in the Teleology of Sierra Leone's 'Senseless War', Uppsala, Nordiska Afrikainstitutet, 2007.

6. For a detailed analysis of the Sierra Leone war and its root causes, see for example RICHARDS Paul, Fighting for the Rainforest: War, Youth and Resources in Sierra Leone, Oxford, International African Institute, 1996; HOFFMAN Danny, The War Machines: Young Men and Violence in Sierra Leone and Liberia, Durham (NC), Duke University Press, 2011; PETERs Krijn, War and Crisis of Youth in Sierra Leone, Cambridge, Cambridge University Press, 2011; KEEN David, Conflict and Collusion in Sierra Leone, Oxford, James Currey, 2005; GBERIE Lansana, A Dirty War in West Africa: The R.U.F. and the Destruction of Sierra Leone, Bloomington, Indiana University Press, 2005; DENOV Myriam, Child Soldiers: Sierra Leone's Revolutionary United Front, Cambridge, Cambridge University Press, 2010; IBRAHIM, Between Democracy and Terror: The Sierra Leone Civil War; TRUTH AND RECONCILIATION Commission, Witness to Truth: Report of the Sierra Leone Truth \& Reconciliation Commission, vol. 3A, 2004.

7. I have discussed the role of roots reggae, Bubu music and commando songs among RUF combatants in more detail elsewhere: NUXoLL Cornelia, “'We listened to it because of the message.' Juvenile RUF Combatants and the Role of Music in the Sierra Leone Civil War", Music \& Politics, vol. 9, no. 1, 2015. DOI: https://dx.doi.org/10.3998/mp.9460447.0009.104; NUXOLL Cornelia "Borrowed Tunes. Commando and Morale Booster Songs in the Sierra Leone War", Transposition, no. 4, 2014. DOI: https://dx.doi.org/10.4000/transposition.598.

8. Ahmed Janka Nabay had a similar reaction to the appropriation of his music by RUF forces.

\section{ABSTRACTS}

The article focuses on the role of music among RUF combatants fighting in the Sierra Leone civil war. It touches on some widely held notions of music and a general reluctance towards the idea that music can be instrumentalised for violent means. Furthermore, it will address in what way 
the research focus on music was conducive to qualitative interview sessions and direct interactions with former RUF members. Special focus lies on the songs that inspired rebel fighters and how these songs were used to prepare for and accompany violent attacks. The article concludes by exploring and comparing how perpetrators, victims and musicians assess the appropriation of music in the context of violence and how they feel about the songs today.

L'article examine le rôle de la musique pour les combattants du RUF qui se battent dans la guerre civile en Sierra Leone. Il interroge certaines notions générales sur la musique ainsi que la réticence à l'idée que la musique puisse être instrumentalisée à des fins violentes. En outre, il explique de quelle manière le biais de la recherche sur la musique a été propice à des séances d'entretiens qualitatifs et à des interactions directes avec d'anciens membres du RUF. Il prête une attention particulière aux chansons qui ont inspiré les combattants rebelles et sur la façon dont ces chansons ont été utilisées pour préparer et accompagner des attaques violentes. L'article conclut en analysant et en comparant la façon dont les auteurs de violences, les victimes et les musiciens évaluent l'appropriation de la musique dans un contexte violent et ce qu'ils ressentent aujourd'hui à propos de ces chansons.

\section{INDEX}

Keywords: Sierra Leone war, RUF, music, violence, music as a weapon, agency, fieldwork experiences, anthropology and music research

Mots-clés: guerre civile de la Sierra Leone, RUF, musique, violence, guerre, musique comme arme, agentivité, expériences de terrain, sociologie de la musique, anthropologie et recherche musicale

\section{AUTHOR}

\section{CORNELIA NUXOLL}

Cornelia Nuxoll is a social anthropologist with a focus on ethnomusicology in sub-Saharan Africa. Currently an independent scholar, she previously was a member of the interdisciplinary research group Music, Conflict and the State at the Georg August University of Göttingen in Germany, which focused on the role of music in promoting, facilitating and perpetuating violent responses to conflict settings and in connection with war crimes and crimes against humanity. Within the framework of her PhD thesis, she conducted fieldwork in Sierra Leone on the role and impact of music among juvenile RUF combatants fighting in the Sierra Leone civil war. 